\title{
The Formulating Growth Strategy of Aceh Port System in Indonesia: An AHP Approach
}

\author{
Muhammad Subhan \\ Institute for Aceh Strategic Development (IASD), and Senior Lecturer (Visiting), Department of International \\ Business, Universiti Utara Malaysia
}

\author{
Ahmad Bashawir Abdul Ghani \\ Senior Lecturer, Department of International Affairs, Universiti Utara Malaysia
}

\begin{abstract}
The main objective of this study is to investigate the growth strategy of Aceh's ports in order to develop a better position of those ports in the dynamic and competitive environment along the Malacca straits. Using the analytic hierarchy process (AHP) approach, this study examines priority perspectives on strategy formulation from 25 individuals representing relevant parties in the Aceh port industry such as government officials, port authorities and managements, experts, academicians and consultants, and port user associations. Six potential strategies related to resources, competencies, market share, opportunity share, cooperation, and competitiveness were examined. The findings show that the resource-based strategy and the competence-based strategy are ranked as first and second important strategy respectively while the opportunity share strategy ranked as the least important strategy. This study provides new insights into the implications of using various strategy formulations for port growth in developing countries and provides a significant practical contribution to the port authorities.
\end{abstract}

Abstrak: Studi ini bertujuan untuk mengkaji strategi pengembangan pelabuhan-pelabuhan Aceh untuk dapat berkembang ke posisi yang lebih baik dalam kawasan yang mempunyai daya saing yang cukup tinggi dan bersifat dinamik yakni kawasan Selat Malaka. Dengan menggunakan pendekatan 'Analytic Hierarchy Process (AHP),' kajian ini menguji perspektif prioritas dari 25 individu yang mewakili berbagai pihak yang terkait dengan perumusan strategi industri kepelabuhanan di Aceh yaitu pegawai dinas-dinas terkait, pihak manajemen dan pengelola pelabuhan, tenaga pakar, akademisi dan konsultan, serta asosiasi pengguna pelabuhan. Ada enam strategi potensial yang dikaji yaitu yang terkait dengan sumberdaya, kompetensi, pangsa pasar, pangsa peluang, kerjasama, dan persaingan. Hasil kajian menunjukkan bahwa strategi berbasis sumberdaya dan strategi berbasis kompetensi menduduki posisi pertama dan kedua sebagai strategi terpenting dalam pengembangan sistem pelabuhan Aceh, sedangkan strategi berbasis peluang pangsa dianggap sebagai strategi yang kurang penting. Kajian ini juga memberikan pemikiran baru dalam perumusan dan penerapan berbagai strategi untuk pengembangan pelabuhan di negara-negara berkembang dan telah membantu pihak pengelola pelabuhan dalam pengambilan keputusan praktis dalam pengembangan sektor kepelabuhanan.

Keywords: Aceh; AHP technique; growth; Indonesia; infrastructure development; port system; strategy analysis 


\section{Introduction}

Many countries have relied very much upon the port and container system for their international trade, especially through ocean liners. For instance, at least 85 percent of China foreign trades (Peng and Xueyue 2003) and 89.6 percent of the global trades (UNCTAD 2008) are transported using sea transportation.

The number and diversity in type of vessels that pass through the Straits of Malacca is increasing rapidly. More than 50,000 ships use the Straits yearly (Abdul Karim 2007) and more than 30 percent of the vessels are containerships (The National Maritime Portal Malaysia 2008). Most of these containerships will be berthed at several ports in the Straits to load and unload their containers.
However, traffic congestion, growing ship sizes, market growth, and depth limitation in the Straits contribute negatively to the future development of the ports (UNCTAD 2008) especially in the region. As the statistics indicate, commodity demand through containerization has been increasing vastly (Port Aid 2008). Therefore, well-defined strategies are needed for the growth of the ports in the region, such as the development of new or upgraded ports in the deepwater of the region that may function as transshipment or bub port. These will perhaps be sound strategies to sustain competitive advantage.

Concomitant with the increase of containerships, the throughputs activities at several ports in the region and the World are also significantly increasing (PSA 2007; 2008 and Port Aid 2008). The average increase of container throughputs for the world is at 6.7

Table 1. Comparison of Throughputs Activities and Growth in South Asia's Major Ports

\begin{tabular}{|c|c|c|c|c|c|c|}
\hline \multirow{3}{*}{$\begin{array}{c}\begin{array}{c}\text { Port } \\
\text { Rank* }\end{array} \\
1\end{array}$} & \multirow{2}{*}{\multicolumn{2}{|c|}{$\begin{array}{l}\text { Region, Country and } \\
\text { Port Name }\end{array}$}} & \multicolumn{2}{|c|}{ Throughputs (TEU) } & \multirow{2}{*}{\multicolumn{2}{|c|}{$\begin{array}{l}\text { Percent } \\
\text { Growth }\end{array}$}} \\
\hline & & & \multirow{2}{*}{$\frac{2007}{27,900,000}$} & \multirow{2}{*}{$\frac{2006}{24,792,400}$} & & \\
\hline & Singapore & Singapore & & & 12.53 & 15.05 \\
\hline 2 & Port Klang & Malaysia & $7,118,714$ & $6,300,000$ & 13.00 & \\
\hline 3 & Tanjung Pelepas & Malaysia & $5,470,000$ & $4,770,000$ & 14.68 & \\
\hline 4 & Laem Chabang & Thailand & $4,848,478$ & $4,215,817$ & 15.01 & \\
\hline 5 & JNP & India & $4,060,000$ & $3,300,000$ & 23.03 & \\
\hline 6 & Jakarta & Indonesia & $3,900,000$ & $3,347,000$ & 16.52 & \\
\hline 7 & Colombo & Sri Lanka & $3,381,240$ & $3,079,132$ & 9.81 & \\
\hline 8 & Ho Chi Minh & Vietnam & $3,200,000$ & $2,532,000$ & 26.38 & \\
\hline 9 & Manila & Philippines & $2,800,000$ & $2,638,000$ & 6.14 & \\
\hline \multirow[t]{2}{*}{10} & Surabaya & Indonesia & $2,109,677$ & $1,859,737$ & 13.44 & \\
\hline & Total & $64,788,109$ & $56,834,086$ & & & \\
\hline
\end{tabular}

* Ranking is based on 2007 throughputs

Data source: Cargo Systems (2009) and Port Aid (2008), modified by the authors 
million TEU per year. If we look at the throughputs activities at the top 10 main container ports in South Asia where the Malacca Straits is located, we will find that there is a 7.95 million TEU increase or 15.05 percent for the year 2007 as compared to the year 2006 (Table 1).

Aceh, located at the northern tip of Sumatera Island and the west-gate keeper of the Malacca Straits, geographically offers important shipping lanes throughout the region and to ports' hinterland of Indonesia. Strategically, with its rich resources and its position flanked by the fastest growing regions of the world's economy, China on the right side and India on the left side, and its location in one of the major markets of the world's container shipping, Aceh ports naturally have the potential and the capabilities to grow (Achmad 2007).
Recently, the Government of Aceh announced a plan to upgrade and redevelop several ports in Aceh with the assistance of the United Nations for Development Programs (UNDP) and other bodies (Aceh Government 2008). The Aceh port system is comprised of eight ports and five of them face the Malacca Straits. Two of them are deepwater functioning ports (UNDP 2008) i.e. Sabang and Lhokseumawe Port. The position of Sabang Port as a centre for trading has been reconsidered since 1993 in relation to the establishment of Indonesia, Malaysia and Thailand's Growth Triangle (IMT-GT). Sabang has been stated as The Integrated Economic Development Region (KAPET) during President Habibie and as a Free Trade Zone (FTZ) and a Free Port Zone (FPZ) by President Abdurrahman Wahid (Achmad 2007).

Figure 1. Strategic Location of Aceh's Port System

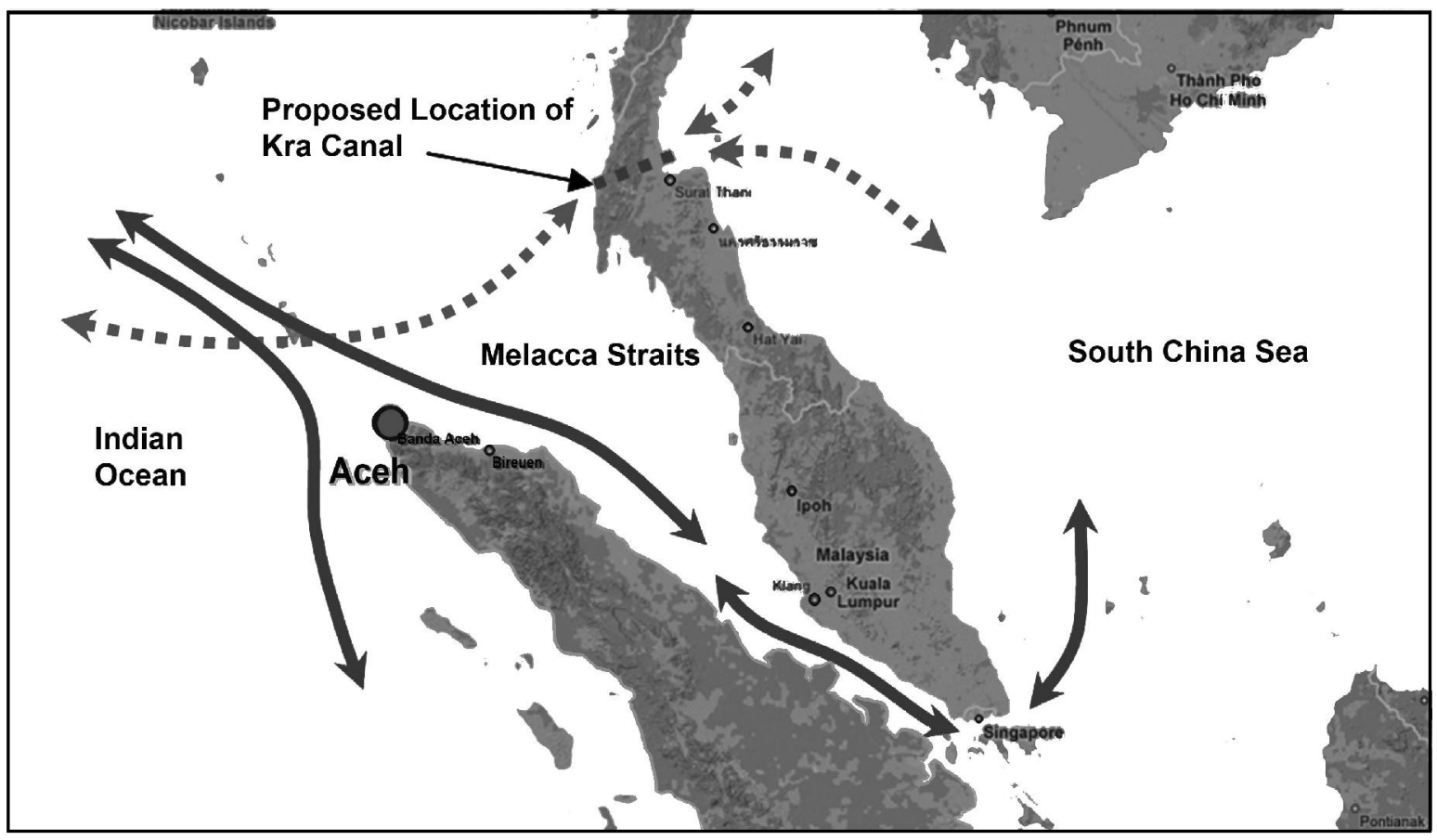

Source: Authors (modified from Google Maps: maps.google.com) 
Aceh, geographically, has advantages of being located at one of the world's busiest shipping routes of the Malacca Strait (Figure 1). With this position, Aceh's ports provide broad accessibility to shippers in addition to its position within IMT-GT regions that have a lot of unique resources that can be used to complement the port's growth. However, despite having those values and resources, Aceh's port system is still having problems growing as major and dynamic ports in Indonesia and in the region. At one point, as pointed out by some above-mentioned authors, many ports including Aceh ports are facing problems of ill-devised and poorly implemented strategies and of unclear mechanisms of port growth in all aspects. At the same time, Aceh ports are surrounded by and are in the shadow of international huge and busy ports like the Port of Singapore, Port Klang and Port of Tanjung Pelepas (PTP) that are always enhancing their capabilities and values, making it extremely difficult for other ports in the region to compete.

\section{Growth Strategies for Aceh Ports}

Apparently there is no single strategy can be considered as powerful enough for the growth strategy of Aceh ports. Devising and formulating various strategies is likely the best thing that the ports can strive for. Each strategy is not superior to the other in general, but appropriateness of the use of the strategy must take into account the levels of competitive environments. There are at least six strategies that Aceh ports can consider for growth (see Figure 2). In some literatures, capability or competency is categorized separately from resource-based strategy but in this paper we describe it jointly simply because capability and competency is part of the port's resources.

Figure 2. Concept for Growth Strategies of Aceh's Port System

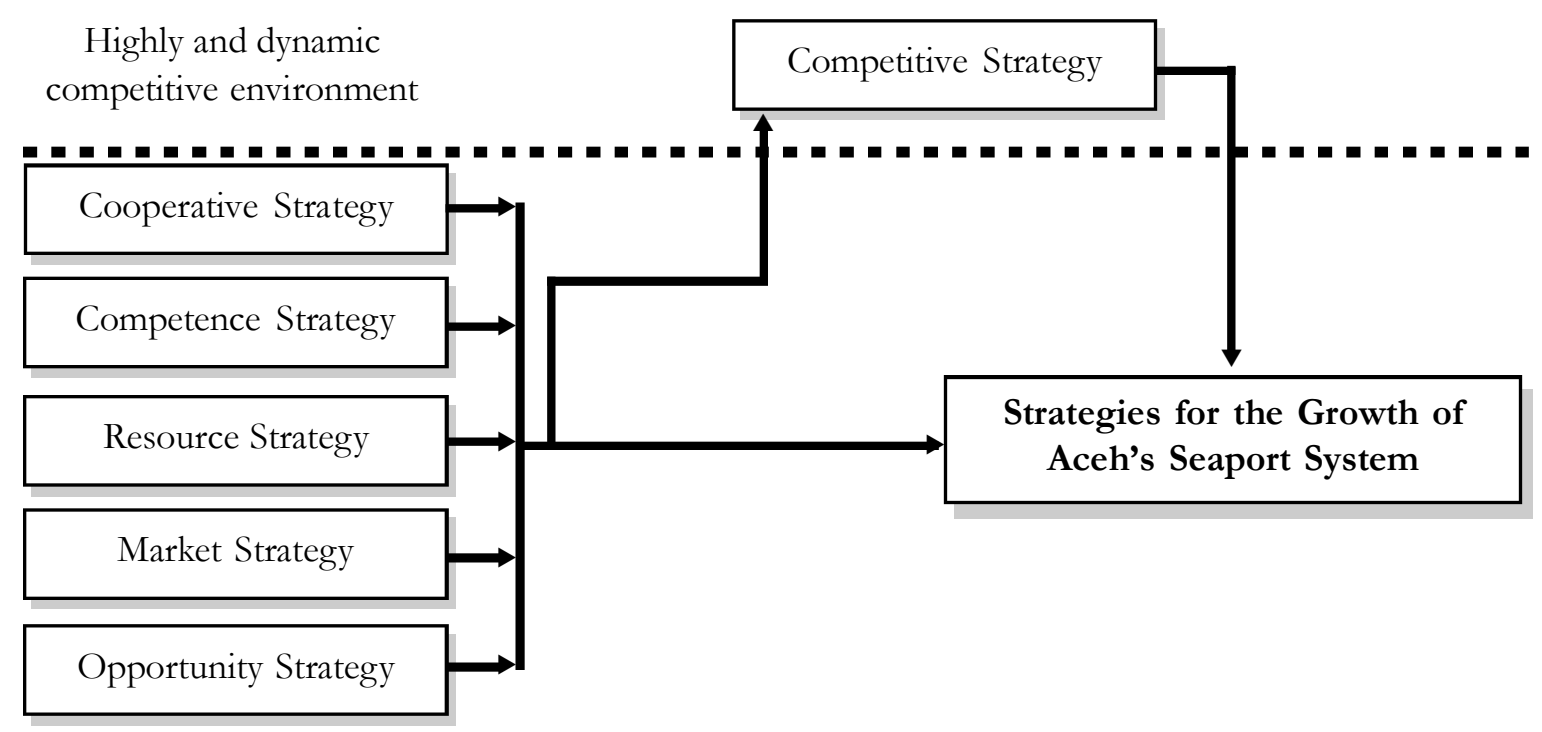

Source: Authors 


\section{Resource-Based Strategy}

In international trade theory, resource is known as one of the most important things that has direct influence on comparative advantage of a country (Krugman and Obstfeld 2009). They are differences in resources that trigger trade transaction between two regions or countries (Krugman and Obstfeld 2009; Feenstra and Taylor 2009).

According to Mahoney and Pandian (1992), resource-based approach is a growing framework that unites main concepts in strategy research that looks at unique competencies and different capabilities of business entities, providing theoretically valueadded suggestion. Barney (1991) puts four features in order a resource be potentially sustained competitive advantage: (a) the resource must have value in the sense that it must trigger opportunity and neutralize threats; (b) it must be rare for the rivals; (c) it must be in-imitable; and (d) it must be nonsubstitutable. Panayides and Gray (1999) believed that resource-advantage theory views the firm as a combiner of heterogeneous and imperfectly mobile resources. Heterogeneous resources may include a firm's knowledge base about markets and specific expertise. Imperfectly mobile resources are those that can be traded but are of more value within the firm or port.

In any port, resources play an important role in contributing to the port's growth as well as in achieving competitive advantage of a port (Subhan and Bashawir 2008; Magala 2004, see Figure 3). From the figure, a port that is struggling to achieve sustainable growth and competitive advantage should employ unique tangible resources combined with core and precise intangible resources.

Figure 3. The Role of Tangible and Intangible Resources in Relation to Growth and Competitiveness

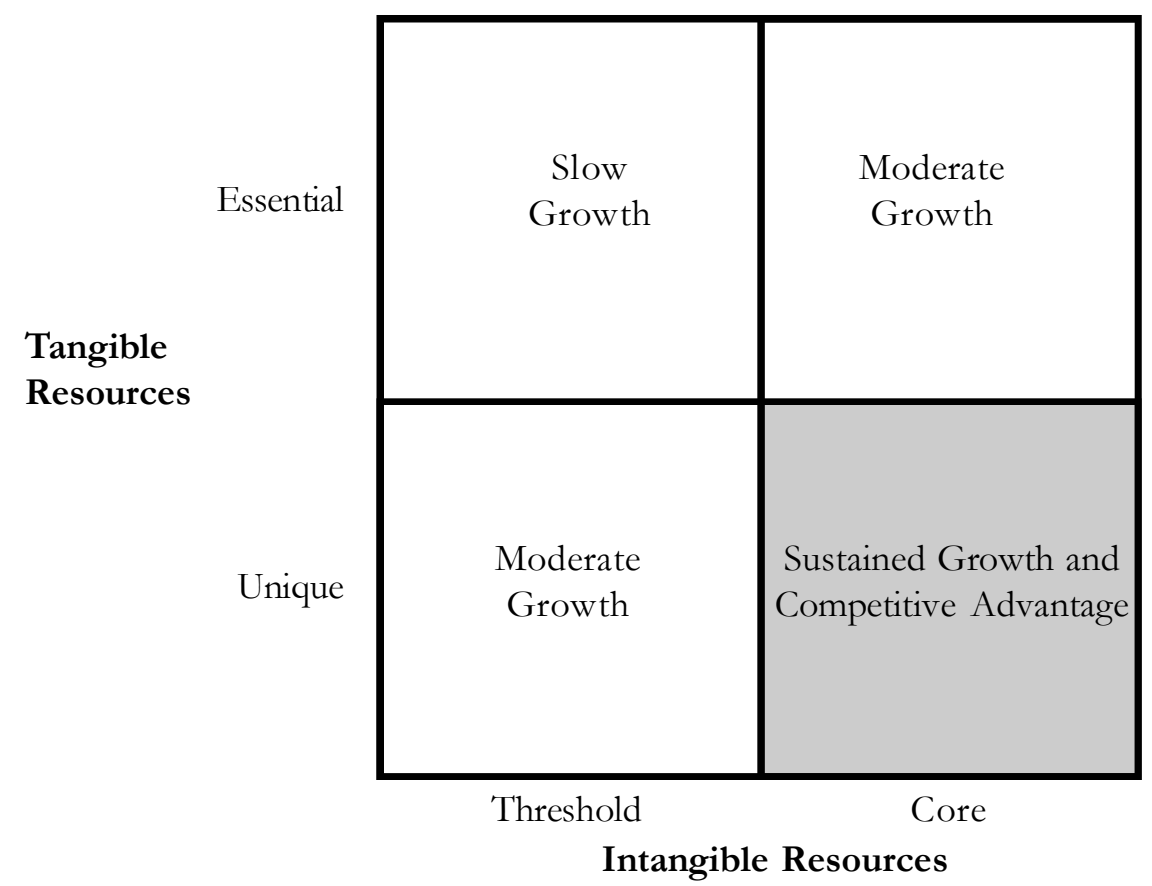

Source: Authors 
Growth, no matter how big or small, is the objective of any firm, including ports and is the sine qua non of a port's industrial success, whereas sustainable growth and competitiveness are the strategic ambitions of any port.

In economics, growth is always reflected by the increase in the production of goods and services, and sometimes incomes, over time through economic activity. Penrose (1956) stated that the factors that determine the size of the increments of expansion that any industrial firm can undertake within a given period of time are factors that determine the rate of growth of the firm. For a port, growth should be defined as the increase in size, number, volume (quantity) or value, strength (quality) of productivities, services, and competitiveness vis-à-vis its competitors that a port can achieve within a particular time.

Common factors of ports' problems that adversely affect their growth and efficiency are the lack of resources available to them such as land availability for expansion, deepwater requirements for handling larger ships, increased port traffic, environmental constraints and local opposition to a port's development (Notteboom and Rodrigue 2005).

\section{Competence-Based Strategy}

Hamel and Prahalad (1994) perceived that core competencies are the soul of a firm. Because of that, a firm or port management has to understand the competent management tasks: (1) identifying existing core competencies; (2) developing core competencies making agenda; (3) developing core competencies; (4) utilizing core competencies; and (5) maintaining and defending core competencies leadership. Many authors (for example Barney 1991; Napier and Nilsson 2006; and
Wang and Ahmed 2007) consider competency and capability as a development or an addition to the resource-based strategy in competition.

In port industry, the ports' capability in handling container throughputs is an important measurement employed to assess the ports' growth and performance. If we look at Table 1, all the ports' performance is based on the throughputs handling per year. Some ports maintain their performance at a 6-10 percent increase per year, while others strive to increase performance at 20-25 percent per year.

For instance, the Port of Tanjung Pelepas in Malaysia started its operation in 1999 with a throughput of only 20,696 TEU that year but it has successfully increased the throughputs dramatically in 2007 to 5.5 million TEU. This achievement places the port as the third busiest port in the region. With the current infrastructure and the current plan for expansion, the port will be capable of handling 8 million TEU annually, to put containers into 29,785 TEU slots with a storage capacity of 200,000 TEU. The port is also capable of handling giant containerships with 14 meters draft currently being operated, and is able to handle future containerships whose draft are less than 19 meters. Moreover, with the dragging works, the port will be able to handle any future container vessels, regardless of size (Subhan and Bashawir 2008).

Aceh ports should formulate a capability or competence-based strategy in accordance with this tendency. They can start with a small amount of container throughputs but with the plan to increase capability from time to time. Skill and knowledge in enhancing the level of effectiveness and efficiency of the port performance should be enhanced to improve reputation in the market. High capa- 
bility to handle port equipments such as crane, storage, pilotage, and towage or the ability to handle information system and technology is of utmost importance in the ports' operation. The Port authority should also be able to connect or link the ports with logistics supply chains and intermodal transports. Concomitant with these activities, the ports should also develop customer loyalty, make use of a supportive policy and regulation by the government and exploit external expertise through strategic alliances with other potential partners. The most important thing that the Aceh port authority should remember is that all activities that are intended to increase the level of competency should be value-added, unique, inimitable, durable, and un-substitutable. Management of Aceh ports should also apply a variety of strategies $^{1}$ to improve the organizational and the operational performances including the modernization of the ports' administration and management; liberalization or de-regulation of the ports' services; commercialization; corporatization; and privatization. In this regard, Aceh can emulate Malaysia in managing the ports as aptly described by Tull and Reveley (2001) that a sound management and a competitive environment are central to port efficiency.

\section{Market Share Strategy}

One of the major points in the growth strategy, according to Robinson (2002), is the use of market-oriented concepts by the firm. This is in accordance with what is believed by Greenwald and Kahn (2005) that a firm's competitive advantage is not indeed based on the size of the firm but it does depend on its differences in market share vis-à-vis its competitors.
In the case of the port industry, the ports need to evaluate the current logistics market that exists. Understanding the market's uncertainty and evaluating low, moderate, and fast growing markets and new markets are some of the most crucial actions that the ports' authority should do as promulgated by many authors. In addition, developing a new market or entering a market with the least number of rivals or serving the un-served costumers are alternative strategies that the ports can consider. The first mover normally enjoys all the advantages without much hassle (Porter 1990).

In relation to market share strategy, Porter (1990) opined that there are three strategies that a firm or port can adopt i.e. cost leadership, differentiation, and focus. To apply this for Aceh ports, they can focus on the diversification of market such as bulk, breakbulk, non-bulk or container cargoes at the beginning stages. However, a plan for specific market should be promulgated in order to implement differentiation, cost leadership and focus in services. For example, the Aceh port system can focus on entering the container market with one deep-sea port as transshipment hub port while others can be feeder ports or distributing ports.

\section{Opportunity Share Strategy}

Opportunity comes in relation to one or more events at a time. Understanding and capturing opportunities is an important strategic activity for the ports in formulating strategies for growth (Kotter 1996; Hamel and Prahalad 1994). In capturing the opportunity, according to Hamel and Prahalad (1994), firms have to answer the following questions: (a) which opportunity share does a firm wants to capture? (b) what are new competencies

${ }^{1}$ The World Bank Port Reform Tool Kit: p. 38. 
that firms have to build?, and (c) how does the existing served market has to change? A firm cannot simply assume that only bigger firms will enjoy all opportunities (Penrose 2009).

In the case of Aceh, the opportunities have been realized by some facts such as the growth in capacity, size, and draft of containerships, the growth of the cargo market, especially the container market in the region, location at the world's busiest container traffic of the Straits of Malacca, an unserved wide hinterland of Sumatera, availability of natural deep-sea for accommodating mega containerships with big draft, and the unavailability of transshipment hub port at the western part of the Straits. As such the Aceh Ports can be considered as getting first movers advantage in the industry in that particular region.

It is estimated (based on Table 1) that about 100 million containers (TEU) pass through Aceh Sea annually. With this amount of container market and a large number of ships, it is a huge opportunity for Aceh ports to grow. In addition to this market, Aceh ports should also look at the un-served hinterland in Sumatera Island or even the whole of Indonesia and other parts in the region. The fact that the port of Belawan in North Sumatera is the only container port in Sumatera is causing the system to face some difficulties and limitations to grow and sustain competitiveness following the fast growing market and maritime technology and highly competitive environment in the region, which should provide opportunity to the Aceh ports. If the Aceh port system can capitalize on this and formulate a sound strategy to serve the unserved hinterland of Sumatera and complement the port of Belawan, then the Aceh ports can get access to a fast growing port in the region. At the same time, competitive strategy components such as cost leadership, differentiation, or focus should be taken into account in formulating this opportunity at different stages.

\section{Competitive Strategy}

In a highly competitive environment, competitive strategy plays an important role for a port to grow and sustain competitive advantage. In this environment, the competitive advantage concepts coined by Porter (1990) can be regarded as still relevant and important for port growth strategy (Robinson 2002; Magala 2004). The aim of the strategy is to compete with its rivals and sustain growth. To achieve this, ports have to create and sustain core businesses and services that are unique to the port and superior to competitors. In addition to the uniqueness, the ports have to think about durability, inimitability, and substitutability and at the same time create values to the businesses and services. These things should be tailored either to shippers and their ancillary service providers or to inland logistics service providers. As pointed out by Porter (1990), those areas that should be given great attention are cost leadership, differentiation and focus of businesses and services.

In port industry, according to Robinson (2002), the port competitive advantage is something created by port users and their partners that provide those port services or in Dussauge and Garette's (1999) words the competitive advantage is created and maintained through a very local (internal) process.

As small ports that intend to grow, Aceh ports should not compete with more established ports like the Port of Singapore and Port Klang but they should establish strate- 
gic alliances with them to grab opportunities, learn skills and competency, and deploy their expertise and resources to support growth, and to some extent rise up to the competitiveness of the ports. At the same time, Aceh ports have to strengthen their infrastructures, reformulate functions and strategies, and increase port investments by identifying, allocating and enhancing their resource values.

\section{Cooperative Strategy or Strategic Alliances}

A long time ago, in most cases, strategic alliances were viewed as not the best solutions, for example, in countries where the investment regulations do not allow the establishment of wholly owned foreign subsidiaries (e.g. Beamish 1988; Harrigan 1986). Moreover, they were perceived to have a negative impact on competitiveness. For example, in his study on the competitive advantage of nations, Porter (1990, p.67) concludes that "alliances appear to be most common among second tier competitors or companies trying to catch up ... (while) global leaders rarely if ever rely on a partner for assets and skills essential to competitive advantage."

In recent years, however, the attention paid to international cooperation has increased, in both theory and practice. Perlmutter and Heenan (1986), for example, argue that increased global competition underlines the necessity to achieve worldwide economies of scale and to cope with internationally diversified customers. In their opinion, only firms that cooperate across national borders will be able to meet these new challenges and compete globally. According to a study by Dyer et al. (2001), the 500 largest firms in the world have an average of 60 major cooperation agreements each. Interna- tional alliances are cooperative arrangements, with cross border flows and linkages that utilize resources from autonomous organizations headquartered in separate countries (Parkhe 1991). According to Holtbrugge (2004), international strategic cooperation has at least three distinct purposes:

1. Scale advantages: Cooperation allows the partner firms to achieve scale economies and reduce excess capacity by combining similar resources that belong to the same stages in the value adding process. This motive is particularly relevant in global industries where large standardization and integration advantages exist (Dussauge et al. 2000; Park and Russo 1996; Porter and Fuller 1986).

2. Resource advantages: Cooperation may also be aimed at combining complementary resources, skills and strengths that belong to different stages in the value adding process. Resource advantages are especially important for partnerships between firms from developed and developing or transformational countries where the former provide management know how, financial resources, and technological capabilities, while the latter contribute access to local customers, suppliers, and government officials (Beamish and Killing 1997; Holbrugge 1995; Sim and Ali 1998).

3. Learning advantages: Cooperation can also be a means for learning and internalizing new skills. This motive is particularly relevant in high tech industries where the ability to acquire and apply knowledge is a key success factor (Kale et al. 2000; Simonin 1999; Stuart 2000).

Resources to any firms including ports are something limited in nature. While competitiveness is continuously growing, the 
ports should think of how to increase competitive advantages of their ports even though their resources are limited. The ports have to add values on the resources and keep strengthening and enhancing those values continuously as described in the competitive strategy. Another effort that the ports can do is to create cooperative strategy or strategic alliances.

By strategic alliances, the ports establish cooperation between the ports and other independent firms which can be other ports or logistics companies or other related service providers. In forming strategic alliances, the ports may choose to carry out one or more projects or specific activities jointly, wherein certain conditions allow members of the alliances to deploy their necessary skills and resources to perform the tasks. In many cases, resources provided by alliance partners from the alliances were able to strengthen their competitive position (Subhan and Bashawir 2008).

To grow and achieve sustainable competitive advantage, Aceh ports should form strategic alliances with several firms and service providers. Alliances with major ports in the region such as the Port of Singapore, Port Klang, and PTP can be considered as a good strategy for Aceh since those ports have superior capabilities and competencies as well as the resources that the Aceh ports can learn from and utilize. Another alternative is to form alliances with ports in the world's fastest growing economies, like China and India, as the economies of these two countries promise a very high growth container market for the ports. Cooperation with other multimodal transport firms, shippers, and inland logistics service providers is necessary to ensure the smooth distribution of the commodities to the ports. At the initial stage, Aceh ports should collaborate with as many parties possible and gradually reduce the alliances selectively to those parties that strategically present benefits and advantages to Aceh ports.

\section{Method and Analysis}

This study employs the analytic bierarchy process (AHP) approach in the analysis to derive the best growth strategy for Aceh port system based on quantitative data gathered from relevant parties in the Aceh port industry such as government officials, port authorities and managements, experts, academicians and consultants, and port user associations. Details and procedure of analysis using the AHP is shown below.

\section{AHP Procedure}

The analytic bierarchy process (AHP) is a theory of measurement that is widely used in industries as a tool to make important decisions related to business, resource allocation, problem priority identification, performance evaluation, and many more (Song and Yeo 2004; Vargas 1990). AHP is based on the principle that, to make decisions, experience and knowledge of people is at least as valuable as the data they use (Vargas 1990). In this study, AHP is used to formulate growth strategy for Aceh port system.

The data used in this study for AHP analysis was obtained through the questionnaire designed specifically for AHP purpose. An instruction to the respondents on how to answer the questions was presented in the questionnaire. Respondents were also given a brief description of the AHP method for analysis and its benefit.

Respondent or informants in this study were individuals from or representing relevant parties in the Aceh port industry such as gov- 
ernment officials, port authorities and managements, experts, academicians and consultants, and port user associations who have engaged or are involved in the formulation of port strategies in Aceh. We can divide the respondents' background into 9 different groups or factions in Aceh, they are: (1) Government officials, (2) Members of local parliament, (3) Members of port authorities and specific economic development authorities, (4) Port operators, (5) Academics whose background relates to port management, (6) Architects and consultants in port planning and development, (7) Professional associations related to port business, (8) Port users, and (9) Other institutions including international organizations whose works relate to port development in Aceh. These groups are chosen due to in practice they play a significant role in the planning process of the port development as well as in developing port strategies in Aceh.

The analysis associated with AHP requires three steps (Song and Yeo 2004), namely: (1) development of a hierarchical structure for analysis (Figure 4), i.e. identification of goal that wants to be achieved, development of criteria that are going to use in the analysis, and identification of several al- ternatives that need to be chosen in the analysis based on the priority; (2) making pair-wise comparisons to yield priorities for the detailed elements of each level, i.e. for every criterion and alternative; (3) synthesizing the priorities into composite measures of the decision alternatives or options.

In the first step, the ultimate goal of the assessment using AHP should be clarified in which in this study the goal is to select the most appropriate strategy based on the hierarchy assessment from the six growth strategy choices or alternatives for the Aceh port system, namely: resource-based strategy, competency-based strategy, market-based strategy, opportunity share strategy, competitive-based strategy, and cooperative-based strategy.

To select alternatives for the growth strategies, a set of criteria must be identified. In this study, four criteria have been used to evaluate and to select the alternatives, namely: (1) Suitability - whether a chosen strategy is suitable with organizational capabilities, position and surrounding environment, and whether a chosen strategy is suitable with the organizational objectives and expectation and its stakeholders, (2) Acceptability - relates to expected results from a

Figure 4. Hierarchy Analysis Structure for AHP Approach

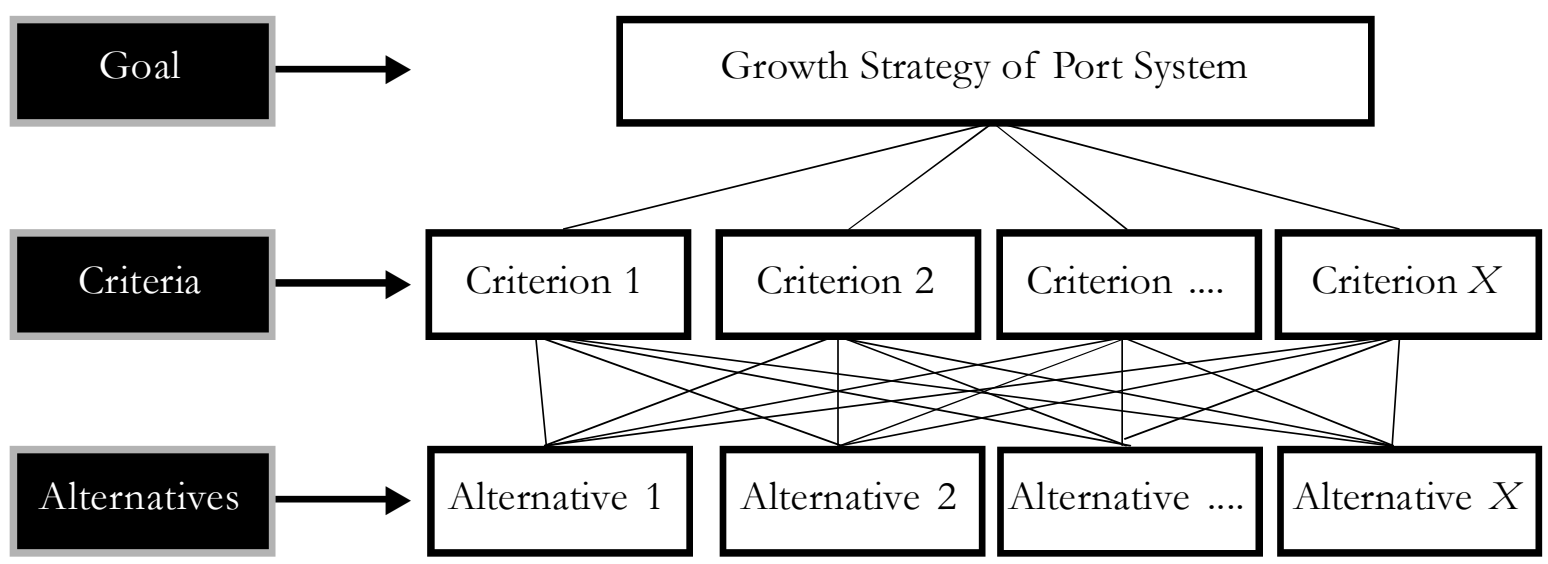


Figure 5. Hierarchy Analysis Structure for Port Growth Strategy Using AHP Approach

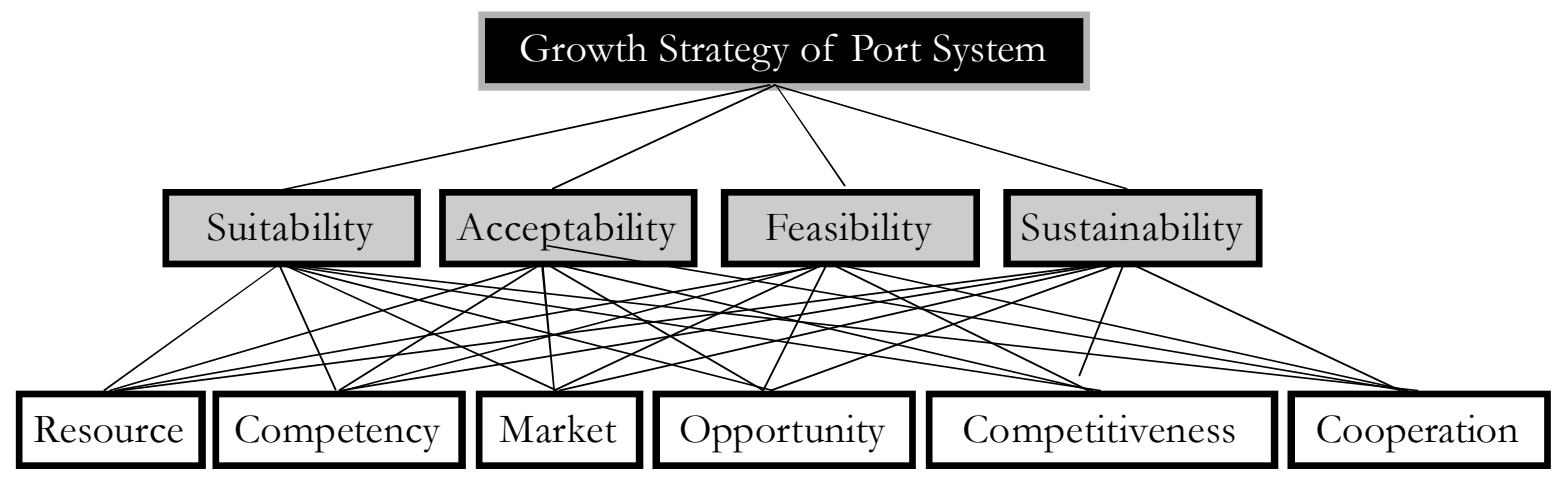

Table 2. Pair-wise Comparison for Criteria Element

\begin{tabular}{lcccc}
\hline Element & Suitability & Acceptability & Feasibility & Sustainability \\
\hline Suitability & 1 & $w_{1} / w_{2}$ & $w_{1} / w_{3}$ & $w_{1} / w_{4}$ \\
Acceptability & $w_{2} / w_{1}$ & 1 & $w_{2} / w_{3}$ & $w_{2} / w_{4}$ \\
Feasibility & $w_{3} / w_{1}$ & $w_{3} / w_{2}$ & 1 & $w_{3} / w_{4}$ \\
Sustainability & $w_{4} / w_{1}$ & $w_{4} / w_{2}$ & $w_{4} / w_{3}$ & 1 \\
\hline
\end{tabular}

Or it can be written as

\begin{tabular}{lcccc}
\hline Element & Suitability & Acceptability & Feasibility & Sustainability \\
\hline Suitability & 1 & $k_{12}$ & $k_{13}$ & $k_{14}$ \\
Acceptability & $1 / k_{12}$ & 1 & $k_{23}$ & $k_{24}$ \\
Feasibility & $1 / k_{13}$ & $1 / k_{23}$ & 1 & $k_{34}$ \\
Sustainability & $1 / k_{14}$ & $1 / k_{24}$ & $1 / k_{34}$ & 1 \\
\hline
\end{tabular}

Figure 6. Matrix for Weight Calculation of the Criteria

$$
\mathrm{A}=\left[\begin{array}{cccc}
\frac{\mathrm{w}_{1}}{\mathrm{w}_{1}} & \frac{\mathrm{w}_{1}}{\mathrm{w}_{2}} & \cdots & \frac{\mathrm{w}_{1}}{\mathrm{w}_{\mathrm{n}}} \\
\cdot & \cdot & \cdot \\
\cdot & \cdot & \cdot \\
\frac{\mathrm{w}_{\mathrm{n}}}{\mathrm{w}_{1}} & \frac{\mathrm{w}_{\mathrm{n}}}{\mathrm{w}_{2}} & \cdots & \frac{\mathrm{w}_{\mathrm{n} 1}}{\mathrm{w}_{\mathrm{n}}}
\end{array}\right] \mathrm{nxn}
$$

strategy involving profit, loss, risks, and reactions from stakeholders, (3) Feasibility whether a firm has resources and competencies to implement a chosen strategy, and (4)
Sustainability - how far a chosen strategy can remain or be sustained as the best strategy for that firm.

Thus, the structure for AHP analysis as shown in Figure 4 has been transformed to as shown in Figure 5 based on the goal, criteria, and alternatives for growth strategies for the Aceh port system.

Next step or in second stage after developing the hierarchical structure for AHP analysis is to make pair-wise comparisons to yield priorities by giving a weight to each criterion and alternative based on respondents' feedback or assessment. The weight (w) is 
presented in the form of a matrix $n \times n$ (see Figure 6) where for every component, the weight is given as $a_{i j}=w_{i} / w_{j}$ where $a_{i i}=1$ and $a_{i j}=1$. From here, we might conclude that if we assume the value of $a_{i j}=k$, then $a_{j i}=1 / k$. In this study, $n=4$, and let $w_{1} / w_{1}, w_{2} / w_{2}, w_{3} /$ $w_{3}, w_{4} / w_{4}$ equals to 1 (see Table 3 )

Out of 31 respondents expected to respond to the questionnaire form in this study, only 25 respondents completed the form that can be used for AHP analysis. Respondents were asked to give their pair-wise comparison for every criterion as well as the alternatives by indicating relative importance in a form of 9 scales as follows: 1 = equal importance; $3=$ moderate importance; $5=$ strong importance; $7=$ very strong importance; $9=$ extreme importance, whereas other scales or numbers i.e. $2,4,6$, and 8 fall within the above numbers. For example, number 2, falls between numbers 1 and 3; number 4, between numbers 3 and 5; and so forth.

\section{Criteria for Selecting Strategy}

Based on data gathered in this study, evaluation matrix for pair-comparison is created and the result is shown as in Table 4. Decimal value used for reporting purposes here are two digits, except for the final or concluding analysis, in which we use four decimal digits.

From the matrix (Table 3), we need to normalize the matrix for the criteria evaluation. The following procedure is used in transforming the pair-comparison matrix into a normalization matrix. Given $a_{i j}$ is every component in the pair-comparison matrix and $A_{i j}$ is every component in the normalization matrix, and then we can calculate:

$$
\begin{aligned}
\mathrm{A}_{11}= & \left(\mathrm{a}_{11} / \text { total weight in column } 1\right)= \\
& (1 / 1+1.68+3.94+3.65)=0.10 \\
\mathrm{~A}_{12}= & \left(\mathrm{a}_{12} / \text { total weight in column } 2\right)= \\
& (4.68 / 4.68+1+3.65+4.15)=0.35
\end{aligned}
$$

Table 3. Evaluation Matrix for Pair-wise Comparison for Criteria Element

\begin{tabular}{lcccc}
\hline Criteria & Suitability & Acceptability & Feasibility & Sustainability \\
\hline Suitability & $\mathbf{1}$ & 4.68 & 2.58 & 3.30 \\
Acceptability & 1.68 & $\mathbf{1}$ & 2.54 & 1.94 \\
Feasibility & 3.94 & 3.65 & $\mathbf{1}$ & 2.41 \\
Sustainability & 3.65 & 4.15 & 3.66 & $\mathbf{1}$ \\
\hline Total & 10.28 & 13.47 & 9.78 & 8.65 \\
\hline
\end{tabular}

Table 4. Normalized Matrix for Criteria Evaluation

\begin{tabular}{lcccccc}
\hline Criteria & Suitability & Acceptability & Feasibility & Sustainability & \multicolumn{2}{c}{ Average Rank } \\
\hline Suitability & 0.10 & 0.35 & 0.26 & 0.38 & 0.27 & {$[2]$} \\
Acceptability & 0.16 & 0.07 & 0.26 & 0.22 & 0.18 & {$[4]$} \\
Feasibility & 0.38 & 0.27 & 0.10 & 0.28 & 0.26 & {$[3]$} \\
Sustainability & 0.36 & 0.31 & 0.37 & 0.12 & 0.29 & {$[1]$} \\
\hline Total & 1.00 & 1.00 & 1.00 & 1.00 & 1.00 & \\
\hline
\end{tabular}


Similar calculation performed for every component to complete the normalization process. The result (normalized matrix) is shown as in Table 4. From Table 4, we can see that sustainability is ranked as the most important criterion for selecting and evaluating the strategies in this study with 30 percent.

The importance of sustainability criterion in strategy formulation is followed closely by suitability and feasibility. Meanwhile, the acceptability criterion is situated at the last position of the most important criteria in formulating growth strategies for the port system.

\section{Evaluation of Strategy Alternatives}

The next step in the AHP analysis process is to repeat the same steps and procedure for getting pair-comparison matrices and normalized matrices for all strategy alternatives (six strategies) for every criterion (four criteria). The first criterion used for the evaluation is suitability. The pair-comparison matrix for the suitability criterion is shown as in Table 5. Next, this matrix is transformed into the normalized matrix as shown in Table 6.

Table 5. Evaluation Matrix for Pair-wise Comparison for Suitability Criterion

\begin{tabular}{lcccccc}
\hline Alternatives & Resource & Competency & Market & Opportunity & Competition & Cooperation \\
\hline Resource & $\mathbf{1}$ & 2.99 & 2.33 & 3.37 & 3.56 & 4.52 \\
Competency & 3.36 & $\mathbf{1}$ & 4.17 & 3.90 & 3.88 & 3.98 \\
Market & 3.81 & 2.22 & $\mathbf{1}$ & 3.37 & 3.64 & 3.33 \\
Opportunity & 2.87 & 2.45 & 2.84 & $\mathbf{1}$ & 2.51 & 3.42 \\
Competitiveness & 2.51 & 2.86 & 2.97 & 3.45 & $\mathbf{1}$ & 3.49 \\
Cooperation & 1.59 & 2.40 & 2.78 & 2.59 & 2.71 & 1 \\
\hline Total & 15.14 & 13.91 & 16.10 & 17.69 & 17.30 & 19.74 \\
\hline
\end{tabular}

Table 6. Normalized Matrix for Suitability Criterion

\begin{tabular}{lccccccc}
\hline Alternatives & Resource & Competency & Market & Opportunity & Competition & Cooperation & $\begin{array}{l}\text { Average } \\
\text { [Rank] }\end{array}$ \\
\hline Resource & 0.07 & 0.21 & 0.14 & 0.19 & 0.21 & 0.23 & $0.18[2]$ \\
Competency & 0.22 & 0.07 & 0.26 & 0.22 & 0.22 & 0.20 & $0.20[1]$ \\
Market & 0.25 & 0.16 & 0.06 & 0.19 & 0.21 & 0.17 & $0.17[3]$ \\
Opportunity & 0.19 & 0.18 & 0.18 & 0.06 & 0.15 & 0.17 & $0.15[5]$ \\
Competitiveness & 0.17 & 0.21 & 0.18 & 0.19 & 0.06 & 0.18 & $0.16[4]$ \\
Cooperation & 0.11 & 0.17 & 0.17 & 0.15 & 0.16 & 0.05 & $0.13[6]$ \\
Total & 1.00 & 1.00 & 1.00 & 1.00 & 1.00 & 1.00 & \\
\hline
\end{tabular}


It clearly shows that according to suitability criterion, competency-based strategy is positioned as the most important strategy in the port system growth in Aceh. The strategy is perceived as having 20 percent more importance than other strategies. Following in the second and the third positions are resource-based strategy and market share strategy respectively. The last three (less important) strategies are the competitive-based strategy, the opportunity share strategy, and the cooperative-based strategy. However, all four middle strategies show only slight differences from one another.

Next, we evaluated strategies based on the other criteria. Normalized matrices for acceptability, feasibility, and sustainability criteria are shown as in Table 7 , Table 8 , and Table 9 respectively.

Table 7. Normalized Matrix for Acceptability Criterion

\begin{tabular}{lccccccc}
\hline Alternatives & Resource & Competency & Market & Opportunity & Competition & $\begin{array}{c}\text { Cooperation } \\
\text { Average } \\
\text { [Rank] }\end{array}$ \\
\hline Resource & 0.08 & 0.19 & 0.20 & 0.19 & 0.21 & 0.24 & $0.1846[1]$ \\
Competency & 0.23 & 0.07 & 0.23 & 0.18 & 0.17 & 0.20 & $0.1794[2]$ \\
Market & 0.19 & 0.17 & 0.06 & 0.19 & 0.20 & 0.20 & $0.1679[3]$ \\
Opportunity & 0.22 & 0.19 & 0.17 & 0.06 & 0.15 & 0.17 & $0.1600[4]$ \\
Competitiveness & 0.16 & 0.21 & 0.17 & 0.20 & 0.05 & 0.14 & $0.1557[5]$ \\
Cooperation & 0.13 & 0.17 & 0.17 & 0.18 & 0.21 & 0.06 & $0.1523[6]$ \\
\hline Total & 1.00 & 1.00 & 1.00 & 1.00 & 1.00 & 1.00 & \\
\hline
\end{tabular}

Table 8. Normalized Matrix for Feasibility Criterion

\begin{tabular}{|c|c|c|c|c|c|c|c|}
\hline Alternatives & Resource & Competency & Market & Opportunity & Competition & Cooperation & $\begin{array}{l}\text { Average } \\
\text { [Rank] }\end{array}$ \\
\hline Resource & 0.11 & 0.27 & 0.23 & 0.27 & 0.24 & 0.24 & 0.2268 [1] \\
\hline Competency & 0.27 & 0.08 & 0.24 & 0.21 & 0.20 & 0.21 & 0.2016 [2] \\
\hline Market & 0.20 & 0.15 & 0.06 & 0.17 & 0.18 & 0.20 & $0.1605[3]$ \\
\hline Opportunity & 0.12 & 0.18 & 0.17 & 0.06 & 0.17 & 0.16 & 0.1414 [4] \\
\hline Competitiveness & 0.15 & 0.17 & 0.16 & 0.14 & 0.05 & 0.14 & $0.1336[6]$ \\
\hline Cooperation & 0.16 & 0.15 & 0.14 & 0.15 & 0.16 & 0.05 & $0.1360[5]$ \\
\hline Total & 1.00 & 1.00 & 1.00 & 1.00 & 1.00 & 1.00 & \\
\hline
\end{tabular}


Table 9. Normalized Matrix for Sustainability Criterion

\begin{tabular}{lccccccc}
\hline Alternatives & Resource & Competency & Market & Opportunity & Competition & $\begin{array}{c}\text { Cooperation } \\
\begin{array}{l}\text { Average } \\
\text { [Rank] }\end{array}\end{array}$ \\
\hline Resource & 0.08 & 0.28 & 0.21 & 0.22 & 0.23 & 0.24 & $0.2100[2]$ \\
Competency & 0.24 & 0.09 & 0.25 & 0.21 & 0.22 & 0.25 & $0.2110[1]$ \\
Market & 0.16 & 0.12 & 0.05 & 0.17 & 0.15 & 0.16 & $0.1361[5]$ \\
Opportunity & 0.13 & 0.14 & 0.12 & 0.05 & 0.13 & 0.12 & $0.1155[6]$ \\
Competitiveness & 0.18 & 0.20 & 0.18 & 0.17 & 0.06 & 0.17 & $0.1597[4]$ \\
Cooperation & 0.20 & 0.18 & 0.18 & 0.19 & 0.20 & 0.06 & $0.1677[3]$ \\
\hline Total & 1.00 & 1.00 & 1.00 & 1.00 & 1.00 & 1.00 & \\
\hline
\end{tabular}

Unlike the strategy assessment based on the suitability criterion as aforementioned where competency-based strategy is ranked as the most important strategy for growth for the port system, with the acceptability criterion, we can see that resource-based strategy and competency-based strategy have similar importance (see Table 7), that is 18 percent. We can see the differences of the prioritized strategies in which the resource-based strategy is the most important strategy among others based on acceptability criterion.

The last criterion used in evaluating growth strategies for Aceh's port system is the sustainability criterion. Table 9 shows that competence-based strategy is perceived as the most important strategy according to the sustainability criterion in formulating strategies for growth for Aceh's seaport system. This strategy (21.10 percent) is slightly different from resource-based strategy (21.0 percent). Cooperative-based strategy (16.77 percent) is positioned as the third most important strategy based on the criterion.

\section{Results}

The importance of overall strategies based on their ranking needed to be analyzed before a general conclusion could be generated using the AHP approach. To do the analysis, the following procedures needed to be conducted. Given:

As $_{i} \mathrm{k}_{j}=$ average normalized weight or score for strategy $i$ based on criterion $j$

$\mathrm{K}_{i} \quad$ = average normalized weight or score for every criterion in strategy $i$

$\mathrm{T}_{i} \quad=$ overall score or weight for strategy $i$

Then, $\mathrm{T} i=$ total average normalized weight or score for every strategy $i$ based on criterion $j$ multiplied by an average normalized weight or score for every criterion in strategy $i$. Or mathematically can be written for every strategy (6 strategies) as follows:

$$
\begin{aligned}
\mathrm{T}_{1}= & \left(A \mathrm{As}_{1} \mathrm{k}_{1} * \mathrm{~K}_{1}\right)+\left(\mathrm{As}_{1} \mathrm{k}_{2} * \mathrm{~K}_{2}\right)+\left(\mathrm{As}_{1} \mathrm{k}_{3} * \mathrm{~K}_{3}\right) \\
& +\left(\mathrm{As}_{1} \mathrm{k}_{4} * \mathrm{~K}_{4}\right) \\
\mathrm{T}_{2}= & \left(\mathrm{As}_{2} \mathrm{k}_{1} * \mathrm{~K}_{1}\right)+\left(\mathrm{As}_{2} \mathrm{k}_{2} * \mathrm{~K}_{2}\right)+\left(\mathrm{As}_{2} \mathrm{k}_{3} * \mathrm{~K}_{3}\right) \\
& +\left(\mathrm{As}_{2} \mathrm{k}_{4} * \mathrm{~K}_{4}\right)
\end{aligned}
$$




$$
\begin{aligned}
\mathrm{T}_{3}= & \left(A \mathrm{As}_{3} \mathrm{k}_{1} \mathrm{~K}_{1}\right)+\left(\mathrm{As}_{3} \mathrm{k}_{2} * \mathrm{~K}_{2}\right)+\left(\mathrm{As}_{3} \mathrm{k}_{3} * \mathrm{~K}_{3}\right) \\
& +\left(\mathrm{As}_{3} \mathrm{k}_{4} * \mathrm{~K}_{4}\right) \\
\mathrm{T}_{4}= & \left(\mathrm{As}_{4} \mathrm{k}_{1} * \mathrm{~K}_{1}\right)+\left(\mathrm{As}_{4} \mathrm{k}_{2} * \mathrm{~K}_{2}\right)+\left(\mathrm{As}_{4} \mathrm{k}_{3} * \mathrm{~K}_{3}\right) \\
& +\left(\mathrm{As}_{4} \mathrm{k}_{4} * \mathrm{~K}_{4}\right) \\
\mathrm{T}_{5}= & \left(\mathrm{As}_{5} \mathrm{k}_{1} * \mathrm{~K}_{1}\right)+\left(\mathrm{As}_{5} \mathrm{k}_{2} * \mathrm{~K}_{2}\right)+\left(\mathrm{As}_{5} \mathrm{k}_{3} * \mathrm{~K}_{3}\right) \\
& +\left(\mathrm{As}_{5} \mathrm{k}_{4} * \mathrm{~K}_{4}\right) \\
\mathrm{T}_{6}= & \left(\mathrm{As}_{6} \mathrm{k}_{1} * \mathrm{~K}_{1}\right)+\left(\mathrm{As}_{6} \mathrm{k}_{2} * \mathrm{~K}_{2}\right)+\left(\mathrm{As}_{6} \mathrm{k}_{3} * \mathrm{~K}_{3}\right) \\
& +\left(\mathrm{As}_{6} \mathrm{k}_{4} * \mathrm{~K}_{4}\right)
\end{aligned}
$$

Using 4-decimal calculations, we got average score for every criterion as follows:

$\mathrm{K}_{1}=0.2726 ; \mathrm{K}_{2}=0.1805 ; \mathrm{K}_{3}=0.2587$; $\mathrm{K}_{4}=0.2883$

From here, an overall evaluation normalized matrix for alternative strategy selection can be calculated as shown in Table 10 . From the table, we can observe that resourcebased strategy is perceived as the most important strategy among other alternative strategies. The importance of resource-based strategy is followed by competence-based strategy with very slight difference that is only 0.04 percent.
From this table, we can conclude that the perceived strategies for growth of Aceh's port system based on their priority are as follows:

1. Resource-based strategy (20.03 percent)

2. Competency-based strategy (19.99 percent)

3. Market share-based strategy (15.84 percent)

4. Competitive-based strategy (15.35 percent)

5. Cooperative-based strategy (14.75 percent)

6. Opportunity share-based strategy (14.04 percent)

From these findings, we can see that the respondent still perceives that resource is the most important factor to be included in port growth strategy, followed by competencies and market. Surprisingly, competencies are viewed as another key factor for the strategy. The respondents believed that the Acehnese have the capability to develop the ports' business, whereas the competitive, cooperative, and opportunity-based strategies are seen as less important than the first three strategies.

Table 10. Overall Evaluation Matrix for All Alternative Strategies

\begin{tabular}{lcccccc}
\hline & $\begin{array}{c}\text { Suitability } \\
\mathbf{( 0 . 2 7 2 6 )}\end{array}$ & $\begin{array}{c}\text { Acceptability } \\
\mathbf{( 0 . 1 8 0 5 )}\end{array}$ & $\begin{array}{c}\text { Feasibility } \\
\mathbf{( 0 . 2 5 8 7 )}\end{array}$ & $\begin{array}{c}\text { Sustainability } \\
\mathbf{( 0 . 2 8 8 3 )}\end{array}$ & $\begin{array}{c}\text { Final } \\
\text { Score }\end{array}$ & Rank \\
\hline Resource & 0.1752 & 0.1846 & 0.2268 & 0.2100 & 0.2003 & {$[1]$} \\
Competency & 0.1999 & 0.1794 & 0.2016 & 0.2110 & 0.1999 & {$[2]$} \\
Market & 0.1738 & 0.1679 & 0.1605 & 0.1361 & 0.1584 & {$[3]$} \\
Opportunity & 0.1527 & 0.1600 & 0.1414 & 0.1155 & 0.1404 & {$[6]$} \\
Competitiveness & 0.1642 & 0.1557 & 0.1336 & 0.1597 & 0.1535 & {$[4]$} \\
Cooperation & 0.1340 & 0.1523 & 0.1360 & 0.1677 & 0.1475 & {$[5]$} \\
\hline Total & 1.0000 & 1.0000 & 1.0000 & 1.0000 & 1.0000 & \\
\hline
\end{tabular}




\section{Conclusions}

There are myriad of strategies one can formulate and apply to any industry or business. In the port industry, however, any strategy selected hinges upon respective port authority. Literature is abounding on the selection of strategy to ensure growth sustainability of a port. In this study, resourcebased strategy was found to be perceived as the most sought after strategy to achieve growth, followed by competence-based and market share-based strategies, contrary to previous research which preferred competitiveness or competitive advantage. This phenomenon is usually true in regional ports or new ports that consider resources as the main driver in port development.

\section{Implication to Policy and Practice}

This paper suggests that the port sector in Indonesia and especially in Aceh needs to drastically reformulate its strategy to gain sustainable growth. This study also suggests that the Aceh port system should focus initially on the resource-based strategy in order to attain significant growth and where necessary, employ both the resource-based and competency-based strategies combined. The consequences, the advantage of the location of the ports and specific services of the ports to the international markets should be ranked at a higher priority rather than merely serving the domestic markets per se. In addition, focusing too much on competitive strategy at the initial stage will result in increasing unnecessary cost in port development and operation. Consolidation is needed before entering into a real highly dynamic and competitive environment of the port industry. In order to synergize the growth strategy, this paper suggests that the Indonesia port systems, in Aceh specifically, needs to accommodate and practice port governance as modeled in the literature (for example World Bank (2007), Notteboom and Winkelmans (2001), Baird (1995) and other scholars) in the sense that there should be a clear role and proportion between port authority and port operator.

\section{References}

Abdul Karim, Z. 2007. The strategic significance of the Straits of Malacca. Australian Defence Force Journal 172: 33-49.

Aceh Government. 2008. Pengembangan Kawasan Sabang Telab Ditetapkan Dalam Master Plan 2007-2012.Available on: http:/ /www.nad.go.id, last accessed 24 ${ }^{\text {th }}$ June 2010.

Achmad, S. 2007. Pelabuhan Bebas (Freeport) Sabang: Antara Harapan dan Fakta. Seminar Penelitian dan Publikasi Sosio-Ekonomi. Banda Aceh: Tunas Research Institute \& the World Bank.

Baird, A. J. 1995. Privatisation of trust ports in the United Kingdom: review and analysis of the first sales. Transport Policy 2 (2): 135-143.

Barney, J. 1991. Firm resources and sustained competitive advantage. Journal of Management 17 (1): 99-120.

Beamish, P. W. 1988. Multinational Joint Ventures in Developing Countries. London-New York: Routledge.

Beamish, P. W., and J. P. Killing. 1997. Cooperative Strategies: Asian Pacific Perspectives. San Francisco, CA: New Lexington Press. 
Cargo Systems. 2009. CS Top 100 Container Ports 2008 (Editor: Benedict Young, August 2008). London: Informa, Available for members on: www.cargosystems.net, last accessed 24 ${ }^{\text {th }}$ June 2010.

Dussauge, P., B. Garrette, and W. Mitchell. 2000. Learning from competing partners: Outcomes and Durations of scale and link alliances in Europe, North America and Asia. Strategic Management Journal 21: 99-136.

Dussauge, P., and B. Garette. 1999. Cooperative Strategy - Competing Successfully Through Strategic Alliances. Singapore: John Wiley \& Sons.

Dyer, J. H., P. Kale, and H. Singh. 2001. How to Make Strategic Alliances Work. MIT Sloan Management Review, 42 (4), 37-43.

Feenstra, R. C., and A. M. Taylor. 2009. International Economics. New York: Worth Publishers.

Greenwald, B., and J. Kahn. 2005. Competition Demystified: A Radically Simplified Approach to Business Strategy. London: Penguin Group.

Harrigan, K.R. 1986. Managing for Joint Venture Success. Lexington, MA: Lexington Books.

Holtbrugge, D. 1995. Personal Management in Osteuropa. Gestaltung Effizienz. Wiesbaden: Gabler.

Holtbrugge, D. 2004. Management of international strategic business cooperation: Situational conditions, performance criteria, and success factors. Thunderbird International Business Review 46 (3): 255-274.

Kale, P., H, Singh, amd H. Perlmutter. 2000. Learning and protection of proprietary assets in strategic alliances: Building relational capital. Strategic Management Journal 21: 217-237.

Kotter, J. P. 1996. Leading Change. Boston: Harvard Business School Press.

Krugman, P. P., and M. Obstfeld. 2009. International Economics: Theory and Policy ( (th $^{\text {th }}$ ed.). New York: Pearson-Addison Wesley.

Magala, M. 2004. Opportunity capture and growth strategies for regional ports: A modeling approach. PhD Thesis. Victoria University, Melbourne.

Mahoney, J. T., and J. R. Pandian. 1992. The resource based view within the conversation of strategic management. Journal of Business Research 33: 91-101.

Napier, N. K., and M. Nilsson. 2006. The development of creative capabilities in and out of creative organizations: Three case studies. Creativity and Innovation Management 15 (3): 268-278.

Notteboom, T. E., and J. P. Rodrigue. 2005. Port regionalization: Towards a new phase in port development. Maritime Policy and Management 32 (3): 297-313.

Notteboom, T. E., and W. Winkelmans. 2001. Structural change in logistics: How will port authorities face the challenge? Maritime Policy and Management 28 (1): 71-89.

Panayides, P. M., and R. Gray. 1999. An empirical assessment of relational competitive advantage in professional ship management. Maritime Policy and Management 26 (2): 111-125.

Park, S. H., and M. V. Russo. 1996. When competition eclipses failure: An event history analysis of joint venture failure. Management Science 42: 875-890.

Parkhe, A. 1991. Interfirm diversity, organizational learning and longevity in global strategic alliances. Journal International Business Studies 22: 579-602.

Peng, H., and Z. Xueyue. 2003. A market study of sea transport between China and Northern Europe. Master Thesis. Sweden: Goteborg University 
Penrose, E. T. 1956. Towards a theory of industrial concentration. The Economic Record (May): 64-77.

Penrose, E. T. 1959. The Theory of the Growth of the Firm. Oxford: Blackwell.

Penrose, E. T. 2009. The Theory of the Growth of the Firm (ed. $4^{\text {th }}$ ). New York: Oxford University Press.

Perlmutter, H. V., and D. A. Heenan. 1986. Cooperate to compete globally. Harvard Business Review (MarchApril): 136-152.

Port Aid. 2008. World Container Terminal Directory. Available on: www.portaid.com, last accessed $18^{\text {th }}$ March 2010

Porter, M. E. 1990. The Competitive Advantage of Nations. New York: The Free Press

Porter, M. E., and M. B. Fuller.1986. Coalitions and global strategy. In M.E. Porter (Ed), Competition in Global Industries: 315-344. Cambridge, MA: Harvard University Press

PSA. 2007, Annual Report 2006. Singapore: PSA International Pte Ltd

PSA. 2008. PS A Singapore Terminals Handles More Than 27 Million TEU of Containers in 2007. Available on: www.singaporepsa.com, last accessed $18^{\text {th }}$ April 2010

Robinson, R. 2002. Ports as elements in value-driven chain systems: The new paradigm. Maritime Policy and Management 29 (3): 241-255

Sim, A. B., and Y. Ali. 1988. Performance of international joint ventures from developing and developed countries: An empirical study in a developing country context. Journal of World Business 33: 357-377.

Simonin, B. L. 1999. Ambiguity and the process of knowledge transfer in strategic alliances. Strategic Management Journal 20: 595-623.

Song, D. W., and K. T. Yeo. 2004. A competitive analysis of Chinese container ports using the analytic hierarchy process. Maritime Economics and Logistics 6: 34-52.

Stuart, T. E. 2000. Interorganizational alliances and the performance of firms: A study of growth and innovation rates in a high technology industry. Strategic Management Journal 21: 791-811.

Subhan, M., and A. Bashawir. 2008. Analyzing growth opportunity of port from the resource-based perspective. Gadjah Mada International Journal of Business 10 (3): 353-373.

Tull, M., and J. Reveley. 2001. Privatisation of ports - An evaluation of the Malaysian experience. Economic Papers 21 (December 2002): 63-79.

UNCTAD. 2008. Globalization of port logistics: Opportunities and challenges for developing countries. UNCTAD Transport Newsletter 38 (first quarter).

Vargas, L. G. 1990. An overview of the analytic hierarchy process and its applications. European Journal of Operational Research 48 (1): 2-8.

Wang, C. L, and P. K. Ahmed. 2007. Dynamic capabilities: A review and research agenda. International Journal of Management Reviews 9 (1): 31-51.

World Bank. 2007. Port Reform Toolkit (2 $2^{\text {nd }}$ ed.). Washington DC: The World Bank. 